Check for updates

The BMJ

fgodlee@bmj.com Follow Fiona on Twitter @fgodlee

Cite this as: BMJ 2020;371:m4701 http://dx.doi.org/10.1136/bmj.m4701 Published: 3 December 2020

\title{
Covid-19: The lost lessons of Tamiflu
}

\section{Fiona Godlee editor in chief}

The history of the covid-19 pandemic will be strewn not only with lost lives and livelihoods but with the bloated carcasses of treatments hyped and bought at great expense, only to be found wanting.

How one such treatment reached its costly prominence, despite the already available evidence of its inadequacies, stands as a cautionary tale. ${ }^{1}$ It also shows how little or how slowly we learn. The remdesivir story shares many common features with the saga of Tamiflu (oseltamivir), the drug that cost the world billions of dollars during the 2009 swine flu pandemic. Both drugs had failed in earlier settings. At the start of the pandemics both were hyped on limited, poor quality research, mainly funded by drug companies. Both were bought in large amounts by governments without data to back up their purchase. Both have harms that have been inadequately researched and reported.

While the truth about Tamiflu emerged only after years of exhaustive work by the Cochrane review group and investigative journalists, ${ }^{2}$ the machinations behind remdesivir's rapid climb were evident at an early stage. On 29 April, the same day as a trial was published showing no significant effect of remdesivir among patients in hospital, remdesivir's manufacturer rushed out interim findings of a more favourable trial by press release and with full White House honours. The much vaunted but minimal benefits shown in severely ill people were used to justify FDA approvals and worldwide purchase. ${ }^{3}$ Now a much larger trial has found little or no benefit in hospital patients, ${ }^{4}$ and a BMJ Rapid

Recommendation, produced in collaboration with the World Health Organization and Magic App, has come down against use of remdesivir in patients with covid-19 of any severity. ${ }^{5}$

Science by press release, on the basis of interim or ad hoc analyses, and without access to the data, also afflicts our knowledge about the covid-19 candidate vaccines. ${ }^{67}$ Patients and the public deserve better than this. So do health professionals. Pandemic or no pandemic, decisions must be based on scrutiny of the full data from trials that are independent of drug and vaccine manufacturers. ${ }^{8}$

The pandemic has had a particular damaging impact on children, ${ }^{9}$ many of whom are going hungry as winter and the economic effects of covid restrictions bite harder. The BMJ Appeal 2020-21 is raising money for the Independent Food Aid Network, which supports a range of organisations across the UK, including more than 400 food banks. ${ }^{10}$ The network's vision is of a country without the need for emergency food aid and in which good food is accessible to all. You can donate at www.foodaidnetwork.org.uk/bmj. Please, as you always have in the past, give generously.
Hsu J. Covid-19: What now for remdesivir?BM/2020:371:m4457. doi: 10.1136/bmj.m4457 pmid: 33214186

2 Tamiflu campaign. BMJ. https://www.bmj.com/tamiflu.

3 Brophy JM. US purchases world stocks of Remdesivir-why the rest of the world should be glad to be at the back of the queue. BMJ Opinion. 3 Jul 2020. https://blogs.bmj.com/bmi/2020/07/03/as-the-us-purchases-worldstocks-of-remdesivir-why-the-rest-of-the-world-should-be-glad-to-be-atthe-back-of-the-queue.

4 Schwartz IS, Heil EL, McCreary EK. Remdesivir: a pendulum in a pandemic BMJ2020;371:m4560. doi: 10.1136/bmj.m4560 pmid: 33234523

5 Lamontagne F, Agoritsas T, Macdonald H, etal. A living WHO guideline on drugs for covid-19. BM/2020;370:m3379.pmid: 32887691

6 Doshi P. Pfizer and Moderna's "95\% effective" vaccines-let's be cautious and first see the full data. BMJ Opinion. 26 Nov 2020 https://blogs.bmi.com/bmi/2020/11/26/peter-doshi-pfizer-and-modernas95-effective-vaccines-lets-be-cautious-and-first-see-the-full-data.

7 Martin-Moreno IM, Middleton J, Sheek-Hussein M, Green MS. Covid-19 vaccines: where are the data? BMJ Opinion. 27 Nov 2020 https://blogs.bmj.com/bmj/2020/11/27/covid-19-vaccines-where-are-thedata.

8 Moynihan R, Bero L, Hill S, etal. Pathways to independence: towards producing and using trustworthy evidence. BMJ 2019;367:16576. doi: 10.1136/bmj.l6576 pmid: 31796508

9 Aynsley-Green A. Covid-19 could prompt an end to our continued betrayal of childhood. BMJ Opinion. 26 Nov 2020 https://blogs.bmi.com/bmi/2020/11/26/covid-19-could-prompt-an-end-toour-continued-betrayal-of-childhood.

10 Feinmann J. The BMI appeal 2020-21: Independent Food Aid Network gives a voice to those determined to make a difference. $B M$ J 2020;371:m4664doi: 10.1136/bmj.m4664.

This article is made freely available for use in accordance with BMJ's website terms and conditions for the duration of the covid-19 pandemic or until otherwise determined by BMJ. You may use, download and print the article for any lawful, non-commercial purpose (including text and data mining) provided that all copyright notices and trade marks are retained. 